\title{
Dietary Intake and Prevalence of Dental Caries among Five-Year-Old Children in Urban and Rural Areas of Uasin-Gishu County, Kenya
}

\author{
H. K. Wakhungu, G. M. Were, C. A. Serrem and C. J. Kibosia
}

\begin{abstract}
Dental caries is a major public health problem associated with diet and nutrition affecting $60-90 \%$ of children globally with the burden in both industrialized and less industrialized countries undergoing nutrition transition. The aim of this study was to assess the relation between the dietary intake and nutritional status on dental caries prevalence of 5year-old school children in urban and rural areas of UasinGishu County. In this study, 382 five year old children and their parents/caregivers were sampled from urban and rural schools in Uasin-Gishu County to participate in the study. Dental caries status was assessed based on the criteria proposed by WHO for oral health surveys. Structured questionnaires was used to gather information on demographic and socio-economic status. A quantitative food frequency questionnaire was used to collect data on dietary intake. Dietary intake data was analyzed using ENA for SMART computer programmes and the rest of the data was analyzed using the Statistical Package for Social Sciences (SPSS) Version 21 (2007). The prevalence of dental caries stood at $39.3 \%$ with a mean dft of 1.55 and $60.7 \%$ being dental caries free. Children met their nutrient requirements for protein, vitamin $C$, calcium, and phosphorus, but did not meet the requirements for energy, folate, vitamin $\mathrm{A}$, and iron. Many children from urban than rural areas consumed sweets/candies at $33.5 \%$ and $15.3 \%$ respectively. Children from urban areas (288) had the highest mean dft of $1.83 \pm 1.37$ while those from rural areas (154) had a mean dft score of $1.16 \pm 1.13$. This was significantly different $(\mathbf{p}<0.05)$. Overweight was higher in the urban population compared to the rural population at $13.64 \%$ and $8.96 \%$ respectively. The prevalence of underweight was higher in rural areas at $10.7 \%$, stunting at $14.6 \%$ and wasting at $6.8 \%$. There is inadequate intake of Energy, Vitamin $A$ and Iron in the diet consumed by the 5-year-old which might be contributing to dental caries prevalence both in the urban and rural areas of Uasin - Gishu County, Kenya. Children should be fed on nutrient rich foods and cariogenic foods should be consumed occasionally.
\end{abstract}

Index Terms - Cariogenic Foods, Dietary Intake, Dental Caries, Nutritional Status.

\section{INTRODUCTION}

Dental caries is one of the common dental diseases that affect millions of children globally. One of the leading cause of dental caries is the diet, which play an important role in its etiology in dental caries. The prevalence of dental caries seems to be increasing, thanks to the nutrition in transition that is being experienced in developing nations due to

Published on August 16, 2020

Hillary K. Wakhungu, School of Agriculture and Biotechnology, University of Eldoret, Kenya.

(corresponding e-mail: hilwak88@gmail.com)

Gertrude M. Were, School of Agriculture and Biotechnology, University of Eldoret, Kenya. globalization [1]. Globally, 60-90\% of children are afflicted by dental caries with majority of them coming from developing countries.

Diet plays a critical role in the development and progression of dental caries. Research has shown that intake of diets deficient in fluoride, calcium and iron leads to the improper enamel formation that is a risk to the development of caries [2]. On the other hand, intake of refined carbohydrates, especially sucrose have been established in the etiology of dental caries [3]. Intake of foods rich in Vitamins A, D, K, B6, calcium, phosphorous, amino acids lysine and fats have been shown to have inhibitory effect on the development and progression of dental caries. Equally, adequate intake of fruits and vegetables rich in Vitamin $\mathrm{C}$ may also reduce the incidences of dental caries [4].

Studies that have been done in Kenya reveal that dental caries prevalence, especially in preschool children are on the rise. The first Kenya National Oral Health Survey showed that 5-year-old children have the highest prevalence of $46.3 \%$ and a dmft of 1.87 [5]. In Uasin-Gishu County, Kibosia [6] found higher dmft's of 1.97 and 3.30 for rural and urban children respectively, with over $90 \%$ of these dental caries remaining untreated. In these studies, oral hygiene practices of the children and their caregivers was suggested as the main reason for the increase in dental caries. However, studies have suggested that dental caries is caused by a host of factors one of them being the diet [7], [8]. Apart from affecting the social interaction of the children, the pain caused by dental caries results in difficulty in chewing food and thus children do not eat a variety of diet. This leads to poor growth and development [5]. The current study aimed to assess the dietary intake and prevalence of dental caries among 5-yearold children in urban and rural areas of Uasin-Gishu County, Kenya.

\section{Methodology}

\section{A. Study design and sampling procedures}

The present cross-sectional study was carried out to assess the relationship between dental caries and dietary intake of 5year-old children in Uasin-Gishu County. Multi-stage systematic and random sampling techniques were used in this study to select three hundred and eighty-two (382) five-yearold children and their parents/caregivers from urban and rural

(e-mail: gmwere@yahoo.com)

Charlotte A. Serrem, School of Agriculture and Biotechnology, University of Eldoret, Kenya.

(e-mail: charlottejes@gmail.com)

Caroline J. Kibosia, School of Dentistry, Moi University, Kenya.

(e-mail: carokib@gmail.com) 
schools in Uasin-Gishu County to participate in the study.

\section{B. Data collection methods and procedures}

Structured questionnaires was used to obtain data on sociodemographic characteristics of the children who participated in the study. Parents/caregiver of the children were interviewed by the research assistant. Those who were $5 \pm 6$ moths at the time of the study, and those whose parents gave consent were included in the study. School children who cooperated were examined for dental caries by trained dental assistants using the criteria proposed by WHO for oral health surveys. The examinations were performed in the schoolroom with children in a seated position on a school chair; the examiner sat in front of them. Cotton wool was used for drying the teeth, and natural day light was used for proper visibility. A CPI ball-ended probe and a lighted mouth mirror were used as examination tools to score caries. A quantitative food frequency questionnaire (QFFQ) was used to collect data on dietary intake. The QFFQ which was categorized into eleven food groups namely; starchy staples, beverages, legumes, dairy, fruits, vegetables, sugar/sweets, meats, eggs, additives and spreads from which the population source its nutrient intake. The respondents (parents or caregivers of the children) were asked to indicate how many times a day, week, month or year that the children consumed the selected foods in order to estimate the usual diet. Standard portion sizes (cups, plates, spoons, bowls, and rulers) commonly used locally by the respondents were used to help the respondents estimate the correct portion sizes consumed. The respondents were then required to describe the size, of each of his or her child's usual serving as small, medium or large relative to these standard servings.

\section{Ethical review}

The proposal was submitted for approval and research permit obtained from the Institutional Research and Ethics Committee (IREC) Moi University (Approval number: 0001888). Prior to the study, consent was obtained from the various school heads and parents to include their children in the study. A pilot study was carried out before the main study to check for the viability and validity of the study.

\section{Data analysis}

To determine the nutrient intake per day, food portions was multiplied by the number of portions consumed per week and divided by 7 or per month and divided by 30 . An estimated daily nutrient intake was arrived at after analysis of the portion sizes per food consumed and then compare it to the RDA.

\section{RESULTS}

A. Socio-economic characteristics of the parents/caregivers

Approximately $43.9 \%$ of the parents/caregivers had attained University and college education with $11.5 \%$ and $18.6 \%$ having attained primary and secondary education, respectively. Only $1.8 \%$ had no education. On the monthly income, $32.2 \%$ of the parents/caregivers had Ksh. 21,000-50,000 (approximately \$210$\$ 500)$ with $6 \%$ of them reporting a monthly income of $<$ Ksh. 5000 (\$50) per month. This translates to a daily income of about Ksh. 166 (\$1.67) for 6\% of the parents/caregivers (Table I).
TABLE I: SOCIO-DEMOGRAPHIC CHARACTERISTICS OF PARENTS/CAREGIVERS OF SELECTED 5 YEAR OLD SCHOOL CHILDREN

\begin{tabular}{|c|c|c|c|}
\hline Variable & Description & Sample & $\begin{array}{c}\text { Percentage } \\
(\%)\end{array}$ \\
\hline \multirow{6}{*}{$\begin{array}{l}\text { Level } \\
\text { education }\end{array}$} & Incomplete primary & 12 & 3.1 \\
\hline & Complete primary & 44 & 11.5 \\
\hline & Incomplete secondary & 80 & 20.9 \\
\hline & Complete secondary & 71 & 18.6 \\
\hline & University\& college & 168 & 43.9 \\
\hline & None & 7 & 1.8 \\
\hline \multirow[t]{5}{*}{ Occupation } & Farmer & 63 & 16.6 \\
\hline & Civil servant & 125 & 32.8 \\
\hline & Casual laborer & 74 & 19.3 \\
\hline & Self-employed & 104 & 27.1 \\
\hline & Other & 16 & 4.2 \\
\hline \multirow{4}{*}{$\begin{array}{l}\text { Household } \\
\text { income }\end{array}$} & $<$ Ksh. 5000 & 23 & 6.0 \\
\hline & Ksh. $6,000-10,000$ & 66 & 17.2 \\
\hline & Ksh. $11,000-20,000$ & 75 & 19.6 \\
\hline & Ksh. 21,000-50,000 & 123 & 32.2 \\
\hline
\end{tabular}

\section{B. Characteristics of the children}

In the study, 228 children (59.6\%) were from urban areas whereas rural areas had $154(40.36 \%)$, with 192 male $(50.3 \%)$ and 190 female $(49.7 \%)$ (Table II).

TABLE II: CHARACTERISTICS OF 5-YEAR OLD CHILDREN IN URBAN AND RURAL AREAS OF UASIN-GISHU COUNTY, KENYA

\begin{tabular}{cccc}
\hline Variable & Description & Sample & $\begin{array}{c}\text { Percentage } \\
(\%)\end{array}$ \\
\hline \multirow{2}{*}{ location } & Urban & 228 & 59.6 \\
& Rural & 154 & 40.4 \\
\multirow{2}{*}{ Gender } & Male & 192 & 50.3 \\
& Female & 190 & 49.7 \\
\hline
\end{tabular}

\section{Prevalence of dental caries}

Among the 382 children, 150 (39.2\%) had dental caries with a mean dft of $1.55 \pm 1.34$ while 232 children $(60.8 \%)$ had no dental caries (Fig. 1)

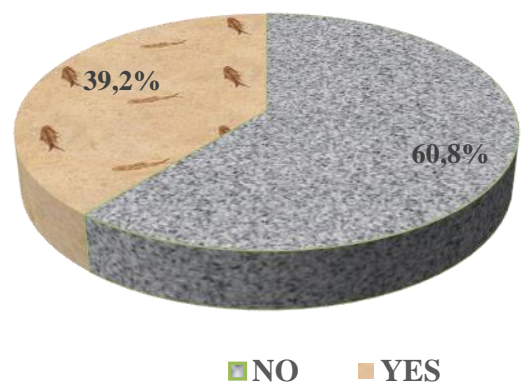

Fig.1: Prevalence of dental caries among 5-year-old children in rural and urban areas of Uasin-Gishu County, Kenya.

\section{Nutrient intake of 5-year-old children}

Data on nutrient intake was collected using QFFQ and analyzed by Nutri-Survey for Windows (2007) revealed that Children in both urban and rural areas met and surpassed the nutrient intake requirements for protein, vitamin $\mathrm{C}$, calcium, and phosphorus, but were unable to meet the daily requirements for energy, folate, vitamin $\mathrm{A}$, and iron (Table III; A and B). 
TABLE III (A): NUTRIENT INTAKE AMONG 5-YEAR-OLD CHILDREN IN URBAN AND RuRAL AREAS OF UASIN-Gishu COUNTY, KENYA

\begin{tabular}{cccc}
\hline Nutrients & Mean intake & RDA $/ \mathbf{E E R}^{\mathbf{b}}$ & Adequacy of Intake \\
\hline Energy & $1321.87 \pm 348.85^{\mathrm{b}}$ & $1600 \mathrm{Kcal}$ & Lower by $45 \%$ \\
Protein & $29.21 \pm 5.94^{\mathrm{a}}$ & $19 \mathrm{~g}$ & Higher by $53.74 \%$ \\
Vitamin A & $382.30 \pm 189.85^{\mathrm{a}}$ & $400 \mu \mathrm{g}$ & Lower by $4.43 \%$ \\
Folate & $135.82 \pm 22.56^{\mathrm{a}}$ & $400 \mu \mathrm{g}$ & Lower by $66.05 \%$ \\
Vitamin C & $49.82 \pm 22.56^{\mathrm{a}}$ & $25 \mathrm{mg}$ & Higher by $99.28 \%$ \\
\hline a Based on & nutrient requirements for children & $4-5$ years old as \\
recommended by IOM (2000) & & \\
b The Estimated Energy Requirement (EER) represents the average \\
dietary energy intake that will maintain energy balance in a healthy person \\
of a given gender, age, weight, height, and physical activity level
\end{tabular}

TABLE III (B): NUTRIENT INTAKE AMONG 5-YEAR-OLD CHILDREN IN URBAN AND RURAL AREAS OF UASIN-GISHU COUNTY, KENYA
E. Consumption frequency of cariogenic foods among the 5year-old children

In this study, consumption of refined sugar snacks was investigated using a Quantitative Food Frequency Questionnaire (QFFQ). As shown in Table 4, children from urban primary schools ate sweets/candies everyday (33.5\%), several times a day $(28.4 \%)$, tea with sugar everyday (58.5\%), pastries several times a week $(54.6 \%)$ and carbonated soft drinks several times a week (44.5\%). Children from rural primary schools ate sweets once a week (27.9\%), several times a week $(43.3 \%)$, tea with sugar every day $(46.5 \%)$, biscuits or queen cakes once a week $(43.7 \%)$, and carbonated soft drinks once a week (40.6\%).

\begin{tabular}{cccc}
\hline Calcium & $\mathbf{4 7 0 . 6 7}_{\mathbf{1 1 3 . 6 4}} \mathbf{1}^{\mathrm{a}}$ & $\mathbf{1 0 0 0} \mathbf{~ m g}$ & Higher by $\mathbf{5 3 \%}$ \\
\hline Phosphorus & $949.32 \pm 291.52^{\mathrm{a}}$ & $500 \mathrm{mg}$ & Higher by $89.86 \%$ \\
Iron & $9.29 \pm 6.81^{\mathrm{a}}$ & $10 \mathrm{mg}$ & Lower by $7.4 \%$ \\
Zinc & $8.92 \pm 2.57^{\mathrm{a}}$ & $5 \mathrm{mg}$ & Higher by $78.4 \%$ \\
\hline
\end{tabular}

TABLE IV: CONSUMPTION FREQUENCY OF SELECTED FOODS AMONG 5-YEAR-OLD CHILDREN IN RURAL AND URBAN SCHOOLS IN UASIN GISHU COUNTY

\begin{tabular}{llccccc}
\hline Foods & Area & $\begin{array}{c}\text { Never } \\
(\boldsymbol{\%})\end{array}$ & $\begin{array}{c}\text { Once a week } \\
(\boldsymbol{\%})\end{array}$ & $\begin{array}{c}\text { Several times a } \\
\text { week }(\boldsymbol{\%})\end{array}$ & $\begin{array}{c}\text { Everyday } \\
(\boldsymbol{\%})\end{array}$ & $\begin{array}{c}\text { Several times a day } \\
(\boldsymbol{\%})\end{array}$ \\
\hline Sweets/Cand & Urban & 0.9 & 23.1 & 14.1 & 33.5 & 28.4 \\
y & Rural & 11.7 & 27.9 & 43.3 & 15.3 & 4.0 \\
Tea with & Urban & 0.1 & 2.41 & 23.2 & 58.5 & 15.9 \\
sugar & Rural & 6.5 & 29.6 & 10.5 & 46.5 & 7.0 \\
Pastry & Urban & 0.0 & 17.5 & 54.6 & 17.9 & 10.0 \\
& Rural & 26.4 & 43.7 & 15.8 & 10.4 & 3.8 \\
Carbonated & Urban & 0.5 & 24.6 & 44.5 & 18.3 & 12.1 \\
drinks & Rural & 24.5 & 40.6 & 25.2 & 6.3 & 3.5 \\
\hline
\end{tabular}

\section{DISCUSSION}

The intake of nutrients plays a crucial role in the eruption, growth, development, and protection of teeth from decay [9], with sufficient intake having significant protective roles while insufficient intake accelerates dental erosion leading to dental caries [3]. Therefore, this study sought to assess the intake of recommended minerals such as calcium, phosphorus, fluoride, iron, and zinc; vitamins A, C, folate as well as protein and energy which play a very important role in dental health in children [10].

\section{A. Vitamin C}

The mean intake of vitamin $\mathrm{C}$ among 5-year-old children in this study was met $(49.82 \mathrm{mg})$. The recommended daily allowance (RDA) is $25 \mathrm{mg}$ for this age group. The adequate intake of vitamin $\mathrm{C}$ might be attributed to the consumption of a variety of fruits such as mangoes and oranges as Uasin Gishu County has a good supply of fruits all-round the year (Uasin Gishu County Integrated Development Plan 20132018).Vitamin $C$ is crucial in the synthesis of collagen, which almost exclusively constitutes the protein portion of teeth and serves as the structural support over which mineralization of teeth occurs [11]. Collagen is necessary for the creation of dentine, pulp, cementum and blood vessels [9]. Based on these functions, vitamin $\mathrm{C}$ plays a critical role in reduction of caries development and progression.

\section{B. Vitamin A}

Mean vitamin A intake among 5-year-old children in this study was $382.30 \mu \mathrm{g}$ against the RDA of $400 \mu \mathrm{g}$ of this age group. This means that the children did not meet their requirements for this nutrient by a small percent (4\%). This could have been due to low consumption of Vitamin A rich foods such as yellow-fleshed sweet potatoes, carrots and pumpkins as well as dark green vegetables. This is a pointer that a section of the children were at risk of Vitamin A Deficiency (VAD). According to a study by Oyunga, Omondi and Grant [12], VAD among young children in Western Kenya was attributed to low intake of vitamin A rich foods.

Apart from its role in healthy vision, vitamin $\mathrm{A}$ is required for the maintenance of the mucosal membranes, salivary glands, teeth and cell integrity [13]. Vitamin A plays a role in the maintenance of the mucosal membranes and salivary glands ensuring a healthy oral cavity free from acidic bacteria that are implicated for dental caries progression in children [7]. The implication of this finding is that a section of the children are at risk of developing and/or faster progression of dental caries due to low intake of vitamin A.

\section{Protein}

Protein supply the Essential Amino Acids (EAAs) is needed for the construction of all body tissues and is essential in protein collagen formation which is involved in the formation of dentin, cementum, periodontal ligaments, and bones [8]. A deficiency in the protein intake is linked to protein-energy malnutrition, enamel hypoplasia, caries of the primary dentition and delayed exfoliation of the primary teeth [14]. The mean protein intake among the five (5) year old children in this study was $29.21 \mathrm{~g}$. Therefore the children met their daily protein requirement. This could be due to the abundance and consumption of legumes that provide a good amount of protein in the diet [15].

\section{Energy}

From the results of the current study, mean energy intake 
of the 5-year-old children was $1321.87 \mathrm{Kcal}$, which was lower than the EER recommendation of $1600 \mathrm{Kcal}$ [16]. This may be attributed to the low intake of oil/fat in the diet which has the highest output of energy ( 9 calories per gram) compared to carbohydrate and protein which provide the body with 4 calories per gram each [17]. A study in Western Kenya among pre-school children also found that children did not meet their energy requirement due to insufficient intake of carbohydrate, fats, and proteins that are the main source of energy in the diet [18]. Optimum energy, especially from carbohydrates, consumed at the right proportions benefit an individual by providing the necessary fuel to support daily activities as well as protein sparing mechanism that allow the protein consumed to be used for dental structure formation and protection. A study by Okemwa et al., [19] on consumption of cariogenic foods among school children in Uasin-Gishu, Kenya observed that excessive energy from consumption of sugar-sweetened beverages, candy, and cookies provides excessive calories which tilts the balance towards the bacterial uses of energy production. This occurrence support the growth of microorganisms that metabolize carbohydrates to produce acidic metabolites causing demineralization of teeth. The implication of the unmet energy consumption in these children is that prolonged energy deficiency will lead to utilization of protein for energy production, leaving little protein for dental development and repair and thus increase the chances of dental caries.

\section{E. Folate}

Mean folate intake of $135.82 \mu \mathrm{g}$ among the preschool children in this study was less than the required RDA of 400 $\mu \mathrm{g}$ for this age group by $66 \%$. This may be attributed to the low consumption of dark green vegetables such as spinach and unsuitable food preparation methods such as boiling. Allen [20] reported that folate deficiency among preschool children is prevalent among children who have a low consumption of green leafy vegetables. Folate plays a major role in the prevention of dental decay by reducing gums inflammation thus making the gums more resilient to dental caries and anaerobic bacteria that causes dental demineralization [21]. A study by Esaki et al., [22] on the relation of folate intake and dental diseases in Japan reported that low serum folate level as a result of insufficient nutrition is associated with the deterioration of dental health and thus the development of dental caries. The inadequate folate intake in this study could be a pointer that children are at risk of dental demineralization.

\section{F. Calcium and phosphorus}

In the present study, the mean calcium intake of children was $470.67 \mathrm{mg}$ which was according to the RDA less by $53 \%$ for five (5) years old children. Low calcium consumption might have been due to milk commercialization by most of the households in Uasin-Gishu instead of feeding it to the children. Kirui and Nguka [23] in a survey on the influence of milk consumption among children $1-5$ years in UasinGishu County established that a smaller percentage of the households $(32 \%)$ fed their children with a mean quantity of $250 \mathrm{ml}$ of milk per week. Tanaka et al., [24] established that daily milk consumption was significantly associated with a lower risk of dental caries in children.
The RDA for Phosphorus among 5-year-old children is $500 \mathrm{mg}$, thus the children in this study met their daily intake. This may be attributed to presence of phosphorus in a variety of foods of both animal and plant sources. Phosphorus is a mineral that helps in building strong bones and teeth enamel thus protecting the teeth against dental caries [25]. Similarly, a study by Lin et al [26] among school children reported phosphorus intake of 1135.96 to $1035.05 \mathrm{mg}$. Phosphorus plays a critical role in the balance between demineralization and remineralization of enamel thus protecting the teeth from dental caries [15].

Calcium and phosphorus are essential in the mineralization of the protein matrix (deposition of hydroxyapatite), therefore giving the bones and teeth their comprehensive strength [27]. A study on the relationship between diet and dental caries in Japan demonstrated that relatively high calcium and Phosphorus intake results in lower dental caries experience in children [25]. Inadequate intake of calcium and phosphorusrich diet not only leads to premature tooth loss but is also associated with severe dental caries [28]. The implication of low intake of calcium and high intake of phosphorus is that it may tilt the synergistic balance of calcium and phosphorus thus placing a section of the children in danger of dental caries.

\section{G. Iron and Zinc}

The RDA for 5-year-olds is $10 \mathrm{mg}$ of Iron and $5 \mathrm{mg}$ of Zinc. Children in Uasin-Gishu had a mean iron and zinc intake of $9.29 \mathrm{mg}$ and $8.92 \mathrm{mg}$, respectively. Therefore, the children met the Zinc requirements but failed to meet the Iron requirements. This could have been caused by low intake of animal source food such as meat, and dark green vegetables such as spinach that is high in Iron. This suggests that some children in this study may have suffered from iron deficiency anemia. The role of iron in the prevention of dental caries has been suggested in studies. Buzafal et al., [29] in a study to determine the effects of iron on inhibition of acid demineralization found out that iron plays a critical role of inhibiting acid demineralization of the enamel by directly affecting mineral dissolution. Therefore, iron deficiency directly leads to dental caries by exposing the teeth to acid demineralization. A study by Tang, Huang and Huang [30] in a study on the relationship of dental caries and anemia among children in China reported a strong association of iron deficiency anemia with dental caries. In another study in Canada, Schroth et al., [2] found that children with dental caries were six times more likely to have iron deficiency anemia than caries-free.

Zinc plays a crucial role in inhibiting the growth of bacteria proliferation in the mouth which in turn leads to reduction in dental caries in children [30]. A study by Sejdini et al., [32] on the role of zinc on dental caries found that zinc concentration is significantly associated with a reduction in caries in children and it is also found to play a critical role in mineralization and maturation of hard tooth tissue that protect the teeth against decay. Were et al., [33] in a study on zinc status in children in Suba District recommended that significant improvement in zinc status of the children and nutrition education can improve zinc status of malnourished children. Therefore, adequate supply of zinc and iron in the diet can go a long way in supporting other measures 
employed in lowering and even eradicating dental caries in children.

\section{H. Consumption frequency of cariogenic foods}

Dietary factors directly associated with the occurrence and severity of dental caries is related to the consumption of high amounts of sugary foods [34]. In the present study, tea with sugar was the most commonly consumed food item on a daily basis at $59 \%$ in urban and $47 \%$ in rural areas. These findings corroborate those reported by the $\mathrm{MoH}$ [5] where the majority of preschool children $(61 \%)$ drunk tea with sugar every day. Results of the current study also indicated that $28 \%$ of the children living in urban areas ate sweets and biscuits several times a day. The sucrose added to candies and processed foods might have led to high dental caries in the urban sample.

In a similar study by Elidrissi \& Naidoo [34] among 5 year old children in Khartoum Sudan, the most consumed food items among 5-year-old in the urban settlements included sweets, candies, chocolate, cakes, biscuits and carbonated soft drinks. In contrast, a study by Wigen \& Wang [36] reported a low likelihood of dental caries in children who had frequent sugar intake. The implication of this finding is children in urban area that have higher consumption of cariogenic foods are at a higher risk of dental caries.

\section{CONCLUSION AND RECOMMENDATIONS}

Based on the results of this study, there is inadequate intake of Energy, Vitamin A and Iron in the diet consumed by the 5year-old both in the urban and rural areas of Uasin - Gishu County, Kenya. The underlying factor may include insufficient consumption, poor selection of foods as well as cooking methods. Urban population have the highest frequency of intake of cariogenic foods compared to the rural children. To reduce the prevalence of dental caries among 5year-old children in Uasin-Gishu County, this study recommends that children should be fed on nutrient rich foods and cariogenic foods should be consumed occasionally. The county health department should promote awareness programs on alternative rich sources of Vitamin A, such as yellow fleshed sweet potatoes, pumpkin and carrots, and Iron rich sources including dark green vegetables such as spinach, use of fortified cereals and red meat.

\section{CONFLICT OF INTEREST}

The author declare that there is no conflict of interest.

\section{ACKNOWLEDGMENT}

The authors are grateful to the University of Eldoret and Moi University for fundamental assistance that was extended to the research project. Research assistants from Department of Family and Consumer Sciences, University of Eldoret and the Department of Pediatric Dentistry and Orthodontics, Moi University are highly appreciated for their work.

\section{REFERENCES}

[1] Do, L.G., Ha, D. H, Spencer, A. J. (2015). Factors attributable for the prevalence of dental caries in Queensland children. Community Dent Oral Epidemiol 2015. John Wiley \& Sons A/S. Published by John Wiley \& Sons Ltd
[2] Schroth, R.J., Levi, J.A., Sellers, E.A., Friel, J., Kliewer, E. \& Moffatt, M.E.K., (2013). Vitamin D status of children with severe early childhood caries: a case-control study. BMC pediatrics, 13(1), p.174.

[3] Arora, A., Scott, J. A., Bhole, S., Do, L., Schwarz, E., \& Blinkhorn, A. S. (2011). Early childhood feeding practices and dental caries in preschool children: a multi-centre birth cohort study. BMC Public Health, 11(1), 28

[4] Pitts, N. B., Zero, D. T., Marsh, P. D., Ekstrand, K., Weintraub, J. A., Ramos-Gomez, F, \& Ismail, A. (2017). Dental caries. Nature reviews Disease primers, 3,17030 .

[5] Ministry of Health (MoH) (2015). Kenya National Oral Health Survey Report 2015, Ministry of Health: Republic of Kenya

[6] Kibosia, C. (2011). Relating Prevalence of Dental Caries to Unmet Treatment Needs Amongst Urban and Rural 5-Year Old Children, Uasin-Gishu, Kenya. Kenya Journal of Health Sciences, Vol. 1, No. 1 Pp 5-9

[7] Vanishree, N., Narayan, R. R., Naveen, N., Anushri, M., Vignesh, D., \& MP, N. R. (2017). Relationship of dental caries and BMI among preschool children of Bangalore city, India: a cross sectional study International Journal of Community Medicine and Public Health, 4(3), 814-819.

[8] Pflipsen, M., \& Zenchenko, Y. (2017). Nutrition for oral health and oral manifestations of poor nutrition and unhealthy habits. General dentistry.

[9] Moynihan, P., \& Petersen, P. E. (2004). Diet, nutrition and the prevention of dental diseases. Public health nutrition, 7(1a), 201-226

[10] WHO, (2003) (World Health Organization) Nutrition. World Health Organization Geneva, Switzerland

[11] Bahal, P., \& Djemal, S. (2014). Dental erosion from an excess of vitamin C. Case reports in dentistry, 2014.

[12] Oyunga, M. A., Omondi, D. O., \& Grant, F. K. E. (2016). Awareness in the Context of Prevalence of Vitamin A Deficiency Among Households in Western Kenya Using a Cross-Sectional Study. Journal of Food and Nutrition Sciences, 4(3), 55-64.

[13] Mobley, C., Marshall, T. A., Milgrom, P., \& Coldwell, S. E. (2009). The contribution of dietary factors to dental caries and disparities in caries. Academic pediatrics, 9(6), 410-414.

[14] Psoter, W.J, Reid B.C \& Katz, R.V. (2005). Malnutrition and dental caries: A review of the literature. Caries Research. 39(6):441-447.

[15] Dror, D. K., \& Allen, L. H. (2014). Dairy product intake in children and adolescents in developed countries: trends, nutritional contribution, and a review of association with health outcomes. Nutrition reviews, 72(2), 68-81

[16] Institute of Medicine (IOM), (2000). Dietary Reference Intakes: Application in Dietary Assessment. National Academy Press, Washington, DC, pp. 73-105.

[17] Austin, G. L., Ogden, L. G., \& Hill, J. O. (2011). Trends in carbohydrate, fat, and protein intakes and association with energy intake in normal-weight, overweight, and obese individuals: 19712006-. The American journal of clinical nutrition, 93(4), 836-843.

[18] Ekesa, B. N., Walingo, M. K., \& Abukutsa-Onyango, M. (2009). Dietary diversity, nutrition status and morbidity of pre-school children in Matungu division, Western Kenya. International Journal of Food Safety, Nutrition and Public Health, 2(2), 131-144.

[19] Okemwa, K.A., Gatongi, P.M \& Rotich, J.K. (2011). The Prevalence of Dental Caries and the Consumption of Cariogenic Foods in Primary School Going Children in Rural Areas of Uasin-Gishu District-Kenya. Kenya Journal of Health Sciences, Vol. 1, No. 1: Pp 22-25

[20] Allen, L. H. (2008). Causes of vitamin B12 and folate deficiency. Food and nutrition bulletin, 29(2_supp11), S20-S34.

[21] Katz, H. (2013), Keep Your Mouth Healthy With Folic Acid. Retrieved from: http://www.therabreath.com/articles/oral-care-tips-andadvice/keep-your-mouth-healthy-with-folic-acid-20163/

[22] Esaki, M., Morita, M., Akhter, R., Akino, K., \& Honda, O. (2010). Relationship between folic acid intake and gingival health in nonsmoking adults in Japan. Oral diseases, 16(1), 96-101.

[23] Kirui, E., \& Nguka, G. (2017). Factors that negatively influence consumption of traditionally fermented milk (Mursik) among preschool children (1-5 years old) in Kapseret location-Uasin Gishu County, Kenya. African Journal of Food, Agriculture, Nutrition and Development, 17(3), 12295-12310.

[24] Tanaka, K., Miyake, Y., Sasaki, S., \& Hirota, Y. (2012). Dairy products and calcium intake during pregnancy and dental caries in children. Nutrition journal, 11(1), 33 .

[25] Yoshihara, A., Watanabe, R., Hanada, N., \& Miyazaki, H. (2009). A longitudinal study of the relationship between diet intake and dental caries and periodontal disease in elderly Japanese subjects. Gerodontology, 26(2), 130-136

[26] Lin, H. S., Lin, J. R., Hu, S. W., Kuo, H. C., \& Yang, Y. H. (2014). Association of dietary calcium, phosphorus, and magnesium intake 
with caries status among schoolchildren. The Kaohsiung journal of medical sciences, 30(4), 206-212.

[27] Subedi, B., Shakya, P. K. C. U., Kc, U., Jnawali, M., Paudyal, B. D., Acharya, A., ... \& Singh, A. (2011). Prevalence of dental caries in 5-6 years and 12-13 years age group of school children of Kathmandu valley. Journal of the Nepal Medical Association, 51(184)

[28] Moshfegh, A., Kovalchik, A.F. \& Clement, J.C. (2016). Phosphorus Intake of Americans. What We Eat in America, NHANES 2011-2012. Food Survey Research Group Dietary Data Brief; No. 15.

[29] Buzalaf, M. A. R., de Moraes Italiani, F., Kato, M. T., Martinhon, C C. R., \& Magalhães, A. C. (2006). Effect of iron on inhibition of acid demineralisation of bovine dental enamel in vitro. Archives of oral biology, 51(10), 844-848.

[30] Tang, R. S., Huang, M. C., \& Huang, S. T. (2013). Relationship between dental caries status and anemia in children with severe early childhood caries. The Kaohsiung journal of medical sciences, 29(6), 330-336.

[31] Lelli, M., Putignano, A., Marchetti, M., Foltran, I., Mangani, F., Procaccini, M., ... \& Orsini, G. (2014). Remineralization and repair of enamel surface by biomimetic $\mathrm{Zn}$-carbonate hydroxyapatite containing toothpaste: a comparative in vivo study. Frontiers in physiology, 5 , 333.

[32] Sejdini, M., Begzati, A., Salihu, S., Krasniqi, S., Berisha, N., \& Aliu, N. (2018). The Role and Impact of Salivary Zn Levels on Dental Caries. International Journal of Dentistry, 2018.

[33] Were, G. M., Ohiokpehai, O., Okeyo-Owuor, J. B., Mbagaya, G. M., Kimiywe, J., Mbithe, D., \& Okello, M. M. (2010). Soybean (Glycine max) complementation and the zinc status of HIV and AIDS affected children in Suba District, Kenya. African Journal of Food, Agriculture, Nutrition and Development, 10(3)

[34] Harris R, Nicoll AD, Adair PM, Pine CM. (2004). Risk factors for dental caries in young children: a systematic review of the literature. Community of Dental Health; 21(1 Suppl):71-85.

[35] Elidrissi, S. M., \& Naidoo, S. (2016). Prevalence of dental caries and tooth brushing habits among preschool children in Khartoum State, Sudan. International dental journal, 66(4), 215-220.

[36] Wigen, T. I., \& Wang, N. J. (2010). Caries and background factors in Norwegian and immigrant 5-year-old children. Community dentistry and oral epidemiology, 38(1), 19-28. 